\title{
SELEKSI PADA SAPI ACEH BERDASARKAN UJI PERFORMANS DI BPTU-HPT SAPI ACEH INDRAPURI
}

\author{
Widya Pintaka Bayu Putra ${ }^{1}$, Sumadi², Tety Hartatik ${ }^{2}$ dan Hendra Saumar ${ }^{3}$ \\ ${ }^{1)}$ Lembaga Ilmu Pengetahuan Indonesia \\ ${ }^{2)}$ Laboratorium Pemuliaan Ternak Fakultas Peternakan Universitas Gadjah Mada, Yogyakarta \\ ${ }^{3)}$ Balai Pembibitan Ternak Unggul - Hijauan Pakan Ternak Sapi Aceh Indrapuri \\ e-mail: banchet_putra18@yahoo.co.id
}

\begin{abstract}
Abstrak
Uji performans merupakan tahap seleksi awal untuk memilih calon pejantan dan induk yang terbaik. Penelitian ini bertujuan untuk mengevaluasi pertumbuhan pada sapi Aceh dewasa. Sebanyak 49 ekor sapi Aceh (23 jantan dan 26 betina) digunakan untuk uji performan selama 369 hari di BPTU-HPT Sapi Aceh Indrapuri. Rata-rata umur sapi sebelum diuji adalah sekitar 600 hari dengan berat awal terkoreksi (BAT) sebesar $110,08 \pm 16,25 \mathrm{~kg}$ (jantan) dan 108,25 $\pm 21,08 \mathrm{~kg}$ (betina). Rata-rata berat akhir terkoreksi (BFT) sebesar 138,30 $\pm 16,59 \mathrm{~kg}$ (jantan) dan 141,63 $\pm 24,88$ $\mathrm{kg}$ (betina). hari (betina). Rata-rata tinggi gumba (TG), panjang badan (PB) dan lingkar dada (LD) setelah pengujian pada sapi jantan masing-masing sebesar 99,07 $\pm 4,64 \mathrm{~cm}, 94,41 \pm 6,21 \mathrm{~cm}$ dan $120,85 \pm 6,41 \mathrm{~cm}$. Selanjutnya rata-rata nilai TG, PB dan LD pada sapi betina setelah pengujian sebesar $97,00 \pm 4,00 \mathrm{~cm}, 95,62 \pm 4,90 \mathrm{~cm}$ dan $124,25 \pm 9,38 \mathrm{~cm}$. Nilai BFT tertinggi selama pengujian sebesar 166,71 kg (jantan) dan 214,19 kg (betina).
\end{abstract}

Kata kunci: Sapi Aceh, uji performans, berat badan, ukuran tubuh

\begin{abstract}
The performance test was the early selection step to select the best candidate bull and cow. This research was conducted to evaluate the growth of Aceh cattle. Amount of 49 animals (23 males and 26 females) were used for performance test along 369 days at BPTU-HPT Sapi Aceh Indrapuri. The average of age before tested was about 600 days with corrected initial weight (CIW) of $110.08 \pm 16.25$ (males) and $108.25 \pm 21,08 \mathrm{~kg}$ (females). The average of corrected final weight $(\mathrm{CFW})$ were $138.30 \pm 16.59 \mathrm{~kg}$ (males) and $141.63 \pm 24.88 \mathrm{~kg}$ (females). The average of withers height $(\mathrm{WH})$, body length (BL) and heart girth $(\mathrm{HG})$ in male cattle were $99.07 \pm 4.64 \mathrm{~cm}, 94.41 \pm 6.21$ $\mathrm{cm}$ and $120.85 \pm 6.41 \mathrm{~cm}$. Therefore, the average of $\mathrm{WH}, \mathrm{BL}$ and $\mathrm{HG}$ in female cattle were $97.00 \pm 4.00 \mathrm{~cm}, 95.62 \pm 4.90 \mathrm{~cm}$ and $124.25 \pm 9.38 \mathrm{~cm}$. Research showed that information of BW in cattle was not affected on final weight. The highest CFW values were $166.71 \mathrm{~kg}$ (male) and 214.19 $\mathrm{kg}$ (female).
\end{abstract}

Key words: Aceh cattle, performance test, body weight, body measurements

\section{PENDAHULUAN \\ Sapi Aceh (Bos indicus)}

merupakan salah satu sapi lokal Indonesia yang memiliki sebaran geografis di Provinsi Aceh. Sapi Aceh ditetapkan sebagai salah satu rumpun sapi lokal di
Indonesia melalui Surat Keputusan Menteri Pertanian RI Nomor: 2907/Kpts/OT.140/6/2011. Populasi sapi potong di Provinsi Aceh pada tahun 2014 tercatat sebesar 511.362 ekor atau sekitar $3,5 \%$ dari populasi sapi potong di 
Indonesia (14.726.875 ekor) pada tahun yang sama. Total pemotongan sapi di Provinsi Aceh pada tahun 2014 sebesar 45.460 ekor atau sekitar 9\% dari total populasi sapi potong di Aceh (DJPKH, 2015). Berdasarkan data statistik peternakan tersebut, maka prospek pengembangan sapi potong di Provinsi Aceh memiliki potensi yang besar.

Sapi Aceh memiliki potensi yang besar untuk ditingkatkan mutu genetiknya. Beberapa keunggulan sapi Aceh antara lain mempunyai daya tahan terhadap lingkungan yang buruk seperti krisis air, pakan, penyakit parasit dan temperatur panas (Gunawan et al., 1998). Rata-rata berat karkas sapi Aceh jantan umur sekitar 2 tahun mencapai 176,05 kg pada berat potong $300 \mathrm{~kg}$ (Fitri, 1991). Salah satu cara untuk meningkatkan mutu genetik ternak adalah dengan melakukan seleksi ternak untuk memilih calon pejantan (bullock) dan calon induk (heifer) yang baik. Salah satu tempat kegiatan seleksi pada sapi Aceh adalah di BPTU-HPT Sapi Aceh Indrapuri. Di lokasi ini seleksi ternak dilakukan berdasarkan peringkat nilai pemuliaan terhadap berat badan 550 hari $\left(\mathrm{NP}_{550}\right)$.

Sapi-sapi yang terpilih berdasarkan $\mathrm{NP}_{550}$ masih perlu dievaluasi pertumbuhannya selama setahun dan disebut dengan uji performan (Hardjosubroto, 1994). Uji performans merupakan salah satu metode uji pada ternak untuk mengetahui sejauh mana tingkat performans atau penampilan sapi untuk memperoleh penampilan terbaik untuk diturunkan pada anaknya saat uji lanjutan (Uji Zuriat). Uji performans dilakukan pada bullock dan heifer yang berumur paling tua 600 hari. Informasi tentang hasil uji performans pada sapi lokal di Indonesia saat ini masih terbatas. Patmawati et al. (2013) melaporkan bahwa rata-rata berat badan pada sapi Bali (Bos javanicus) di BPTU-HPT Sapi Bali pada uji performans selama 9 bulan sebesar 261,56 $\pm 81,20 \mathrm{~kg}$. Selanjutnya Yusuf et al. (2010) melaporkan rata-rata berat badan pada uji performans selama setahun pada sapi Bali di Kabupaten Barru, Provinsi Sulawesi Selatan sebesar $228,80 \pm 28,00 \mathrm{~kg}$. Penelitian ini bertujuan untuk mengevaluasi pertumbuhan sapi Aceh di BPTU-HPT Sapi Aceh Indrapuri yang sudah diseleksi berdasarkan $\mathrm{NP}_{550}$. Hasil penelitian ini diharapkan dapat diperoleh sapi-sapi yang unggul untuk diseleksi kembali dengan uji zuriat.

\section{MATERI DAN METODE}

\section{Lokasi dan Sampel}

Penelitian ini dilakukan di BPTU Sapi Aceh Indrapuri, Kabupaten Aceh Besar, Provinsi Aceh. Lokasi ini terletak di $05^{\circ} 33$ ' $11,8^{\prime}$ ' LU dan $95^{\circ} 17^{\prime} 57,5$ BT serta berada di ketinggian sekitar 30 - 80 $\mathrm{m}$ dpa. Rata-rata kelembaban udara sekitar $81,80 \%$ dengan suhu udara sekitar $27,5{ }^{\circ} \mathrm{C}$ dan rata-rata curah hujan sekitar $1147 \mathrm{~mm} /$ th dan intensitas hujan sekitar 98 hari/th. Data pencatatan ternak (recording) dari tahun 2010 sampai 2013 digunakan dalam penelitian sebagai data primer. Sebanyak 49 ekor sapi Aceh dewasa terdiri atas 23 jantan dan 26 betina digunakan dalam penelitian ini untuk dievaluasi pertumbuhannya.

\section{Manajemen Pemeliharaan}

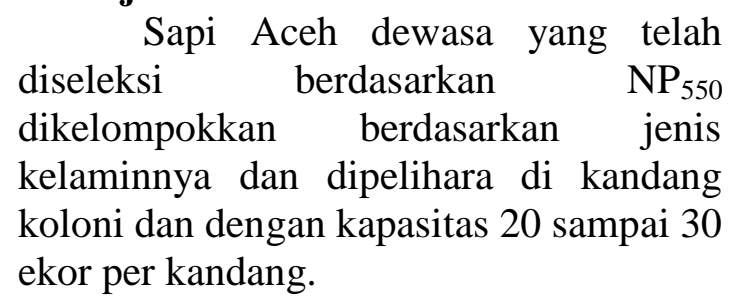


Tabel 1. Standar Nutrisi (\%) pada Sapi Aceh Dewasa di BPTU-HPT Sapi Aceh Indrapuri

\begin{tabular}{cccccccccc}
\hline Sex & KA & Abu & PK & Lemak & Ca & P & NDF & UDP & TDN \\
\hline Jantan & 14 & 12 & 12 & 6 & $0,5-7,0$ & $0,5-0,6$ & 30 & 4,2 & 65 \\
Betina & 14 & 12 & 14 & 6 & $0,8-1,0$ & $0,6-0,8$ & 35 & 5,6 & 65 \\
\hline KA $:$ ra
\end{tabular}

KA: kadar air; PK: protein kasar; Ca: calsium; P: phospor; NDF: neutral detergent fiber; UDP: undigestible protein; TDN: total digestible nutrient

Minuman diberikan secara ad libitum. Pakan diberikan dua kali sehari dan terdiri dari rumput gajah (Pennisetum purpureum ), jerami padi, rumput teki (Cyperus rotundus) dan ampas ketela (onggok). Konsentrat diberikan sebanyak $4 \mathrm{~kg} / \mathrm{ekor} / \mathrm{hari}$. Standar nutrisi sapi Aceh di BPTU-HPT Sapi Aceh Indrapuri tersaji pada Tabel 1. Sapi yang berumur 500 sampai 800 hari digunakan untuk uji performan pada tanggal 26 Januari 2012 sampai 30 Januari 2013 (369 hari) dengan masa adaptasi pakan sebelum diuji adalah satu bulan.

\section{Pengukuran dan Penimbangan}

Pengukuran pada ternak pada penelitian ini dilakukan berdasarkan petunjuk Supiyono (1998) meliputi tinggi gumba (TG), panjang badan (PB) dan lingkar dada (LD) seperti pada Gambar 1.

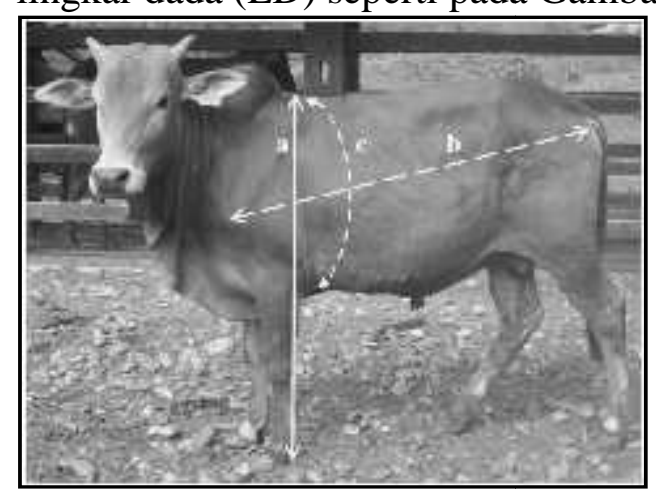

Gambar 1. Skema pengukuran tinggi gumba (a), panjang badan (b) dan lingkar dada (c) pada sapi Aceh jantan

Pengukuran TG $(\mathrm{cm})$ dilakukan menggunakan tongkat ukur dari bagian pundak (Os vertebrae thoracalis III) sampai ke permukaan tanah mengikuti garis tegak lurus. Pengukuran PB $(\mathrm{cm})$ dilakukan dengan mengukur jarak antara sendi bahu (Tuber humerus on Os humerus) sampai ke tepi belakang tulang pelvis (Tuber ischiadicum on Os coxa). Pengukuran LD $(\mathrm{cm})$ diperoleh dengan cara melingkarkan pita ukur mengikuti lingkar dada atau tubuh di belakang bahu (Os costa V). Data berat badan (kg) diperoleh dengan cara menimbang berat hidup ternak pada timbangan ternak dengan posisi ternak tegak lurus dengan bidang datar. Identifikasi umur pada ternak dilakukan berdasarkan catatan kelahiran sapi yang tersedia di lokasi penelitian.

\section{Analisis Data}

Data berat badan pada sapi dianalisis sesuai petunjuk Hardjosubroto (1994) sebagai berikut:

Pertambahan berat $(\mathrm{kg})=$ Berat akhir nyata $(\mathrm{kg})$ - Berat awal nyata $(\mathrm{kg})$

Berat akhir terkoreksi $(\mathrm{kg})=$ Berat akhir terkoreksi $(\mathrm{kg})+$ Pertambahan berat $(\mathrm{kg})$

Keterangan:

$\overline{\mathrm{X}}_{\text {Umur }}=$ Rata-rata umur sapi setelah diuji (hari) atau umur akhir

Data ukuran tubuh pada masingmasing sapi yang telah diuji kemudian dibandingkan dengan standar bibit sapi Aceh (SNI: 7651.3-2013) seperti yang tersaji pada Tabel 2. 
Tabel 2. Standar Bibit Sapi Aceh (SNI: 7651.3-2013)

\begin{tabular}{ccccc}
\hline Jenis kelamin (umur) & Pengukuran $(\mathrm{cm})$ & Kelas A & Kelas B & Kelas C \\
\hline \multirow{3}{*}{ Jantan $(24-36$ bulan) } & Tinggi gumba & 112 & 109 & 105 \\
& Panjang badan & 116 & 113 & 107 \\
& Lingkar dada & 143 & 140 & 135 \\
\hline \multirow{3}{*}{ Betina $(15-18$ bulan) } & Tinggi gumba & 90 & 88 & 86 \\
& Panjang badan & 87 & 84 & 82 \\
& Lingkar dada & 99 & 97 & 94 \\
\hline
\end{tabular}

\section{HASIL DAN PEMBAHASAN}

Rata-rata berat lahir pada sapi Aceh di BPTU-HPT Sapi Aceh Indrapuri tersaji pada Tabel 3. Berat lahir sapi Aceh lebih kecil dibandingkan dengan beberapa sapi lokal Indonesia yang lain seperti Peranakan Ongole/PO $(25.93 \pm 3.97 \mathrm{~kg})$, Sumba Ongole/SO $(21,20 \pm 4,60 \mathrm{~kg})$, Bali $(17.80 \pm 1.08 \quad \mathrm{~kg})$ dan Madura sebesar15.74 $\pm 2.62 \mathrm{~kg}$ (Adinata, 2013; Said et al., 2016; Kaswati et al., 2013; Yusran et al., 1995). Berat lahir pada sapi Aceh juga lebih kecil dibandingkan dengan beberapa bangsa sapi Bos indicus seperti Brahman cross $(31,33 \pm 3,52 \mathrm{~kg})$, Nellore $(32,30 \pm 3,80 \mathrm{~kg})$, Red Chittagong $(16,74 \pm 0,36 \mathrm{~kg})$ dan $20,00 \pm 4,96 \mathrm{~kg}$ pada Malawi Zebu (Muslim et al., 2011; Tatiane et al., 2014; Rabeya et al., 2009; Nandolo et al., 2016).

Berat lahir pada beberapa bangsa sapi Bos taurus antara lain Friesian Holstein $\quad(33.90 \pm 0.90 \mathrm{~kg})$, Angus $(35.40 \pm 3.80 \mathrm{~kg})$, Hereford $(35.20 \pm 4.60$

\section{Berat lahir}

$\mathrm{kg})$ dan Belgian Blue $(49.20 \pm 7.10 \mathrm{~kg})$ menunjukkan angka yang lebih tinggi diandingkan dengan bangsa sapi Bos indicus (Ozkaya, 2013; Nugent et al., 1991; Kolkman et al., 2010). Perbedaan berat badan pada kedua bangsa sapi tersebut disebabkan karena faktor genetik dan lingkungan yang berbeda (Warwick et al., 1989).

\section{Berat dewasa.}

Rata-rata berat dewasa setelah uji performan tersaji pada Tabel 4. Rata-rata berat dewasa sapi Aceh jantan (umur $\pm 2,5$ tahun) dan sapi Aceh betina (umur \pm 3 tahun) pada penelitian ini lebih rendah dibandingkan hasil penelitian Abdullah et al. (2007) yaitu sebesar $153,17 \pm 25,58 \mathrm{~kg}$ (jantan) dan 147,42+22,90 kg (betina). Berat dewasa sapi Bali jantan umur 2 tahun hasil uji performans selama 9 bulan di BPTU-HPT

Tabel 3. Rata-Rata Umur dan Berat Badan pada Sapi Aceh Sebelum Uji Performans

\begin{tabular}{clrrrrr}
\hline Jenis kelamin & \multicolumn{1}{c}{ Performan } & Rata-rata & \multicolumn{1}{c}{ SD } & KV (\%) & \multicolumn{1}{c}{ Min. } & Maks. \\
\hline \multirow{3}{*}{ Jantan } & Umur awal (hari) & 617,35 & 64,51 & 10,45 & 516,00 & 748,00 \\
& Berat lahir (kg) & 12,83 & 0,72 & 5,59 & 12,00 & 14,00 \\
& Berat awal nyata (kg) & 110,43 & 19,91 & 18,03 & 77,00 & 151,00 \\
\hline \multirow{3}{*}{ Betina } & Umur awal (hari) & 645,12 & 74,19 & 11,50 & 531,00 & 753,00 \\
& Berat lahir (kg) & 12,77 & 0,76 & 5,99 & 12,00 & 15,00 \\
& Berat awal nyata (kg) & 108,19 & 22,22 & 20,34 & 72,00 & 166,00 \\
\hline
\end{tabular}

$\mathrm{N}$ : jumlah individu; SD: standar deviasi; KV: koefisien variasi; Min.: nilai minimum; Maks.: nilai maksimum 
Tabel 4. Rata-Rata Umur dan Berat Badan pada Sapi Aceh Setelah Uji Performans

\begin{tabular}{|c|c|c|c|c|c|c|}
\hline Sex & Performan & Rata-rata & SD & $\mathrm{KV}(\%)$ & Min. & Maks. \\
\hline \multirow{5}{*}{ Jantan } & Umur akhir (hari) & 967,13 & 67,42 & 6,97 & 866,00 & 1104,00 \\
\hline & Berat awal terkoreksi (kg) & 110,08 & 16,25 & 14,76 & 77,35 & 138,71 \\
\hline & Berat akhir terkoreksi (kg) & 138,30 & 16,59 & 12,00 & 113,35 & 166,71 \\
\hline & Berat akhir nyata (kg) & 138,65 & 19,46 & 14,04 & 108,00 & 173,00 \\
\hline & Pertambahan berat $(\mathrm{kg})$ & 28,22 & 7,01 & 24,85 & 18,00 & 43,00 \\
\hline \multirow{5}{*}{ Betina } & Umur akhir (hari) & 1003,81 & 75,73 & 7,54 & 888,00 & 1108,00 \\
\hline & Berat awal terkoreksi (kg) & 108,25 & 21,08 & 19,47 & 74,51 & 157,19 \\
\hline & Berat akhir terkoreksi (kg) & 141,63 & 24,88 & 17,57 & 102,65 & 214,19 \\
\hline & Berat akhir nyata (kg) & 141,58 & 25,81 & 18,23 & 101,00 & 223,00 \\
\hline & Pertambahan berat $(\mathrm{kg})$ & 33,38 & 9,92 & 29,73 & 15,00 & 57,00 \\
\hline
\end{tabular}

SD: standar deviasi; KV: koefisien variasi; Min.: nilai minimum; Maks.: nilai maksimum

Sapi Bali sebesar 261,56 $\pm 81,20$ $\mathrm{kg}$ dengan pertambahan berat badan $70,73 \pm 33,53 \mathrm{~kg}$ (Patmawati et al., 2013). dan menunjukkan hasil yang lebih besar dibandingkan pada sapi Aceh pada penelitian ini. Adrial (2010) melaporkan bahwa berat dewasa sapi Katingan (umur 3 tahun) pada jantan sebesar 140,00 $\pm 2,00$ $\mathrm{kg}$ (jantan) dan 139,80 $\pm 19,50 \mathrm{~kg}$ (betina). Dari penelitian tersebut terlihat bahwa sapi Aceh jantan pada penelitian ini memiliki berat badan yang lebih rendah daripada sapi Katingan, akan tetapi pada sapi Aceh betina memiliki berat badan yang lebih tinggi.
Berat dewasa pada sapi Aceh pada penelitian ini menunjukkan hasil yang lebih tinggi dibandingkan dengan sapi Red Chittagong di Bangladesh yaitu sebesar 127.40+7.34 kg pada jantan (umur 900 hari) dan $111,55 \pm 3,47 \mathrm{~kg}$ (umur 810 hari) pada betina seperti yang dilaporkan oleh Nahar et al. (2016). Mashiloane et al. (2011) melaporkan bahwa berat akhir (umur 545 hari) setelah uji performans selama setahun pada sapi Bonsmara $(389,71 \pm 29,21 \mathrm{~kg})$ dan Nguni $(304.33 \pm 27.23 \mathrm{~kg})$ menunjukan nilai yang lebih tinggi dibandingkan pada penelitian ini.

Tabel 5. Rata-rata Ukuran Tubuh Sapi Aceh Setelah Uji Performans Selama Setahun

\begin{tabular}{|c|c|c|c|c|c|c|c|}
\hline Test & Sex & $\begin{array}{l}\text { Ukuran tubuh } \\
(\mathrm{cm})\end{array}$ & $\begin{array}{c}\text { Rata-rata } \\
(\mathrm{cm})\end{array}$ & $\mathrm{SD}$ & $\mathrm{KV}(\%)$ & Min. & Maks. \\
\hline \multirow{6}{*}{ Awal } & \multirow{3}{*}{ Jantan } & Tinggi gumba & 94,00 & 4,81 & 5,12 & 83,00 & 103,00 \\
\hline & & Panjang badan & 88,81 & 4,57 & 5,14 & 79,00 & 88,00 \\
\hline & & Lingkar dada & 110,86 & 6,83 & 6,16 & 98,00 & 125,00 \\
\hline & \multirow{3}{*}{ Betina } & Tinggi gumba & 93,27 & 4,32 & 4,63 & 87,00 & 102,00 \\
\hline & & Panjang badan & 88,75 & 6,18 & 6,97 & 82,00 & 105,00 \\
\hline & & Lingkar dada & 111,54 & 8,20 & 7,35 & 95,00 & 130,00 \\
\hline \multirow{6}{*}{ Akhir } & \multirow{3}{*}{ Jantan } & Tinggi gumba & 99,07 & 4,64 & 4,68 & 89,00 & 110,00 \\
\hline & & Panjang badan & 94,41 & 6,26 & 6,64 & 84,00 & 105,00 \\
\hline & & Lingkar dada & 120,85 & 6,41 & 5,31 & 108,50 & 132,00 \\
\hline & \multirow{3}{*}{ Betina } & Tinggi gumba & 97,00 & 4,00 & 4,12 & 90,50 & 105,00 \\
\hline & & Panjang badan & 95,62 & 4,90 & 5,12 & 85,00 & 103,00 \\
\hline & & Lingkar dada & 124,25 & 9,38 & 7,55 & 111,00 & 145,00 \\
\hline
\end{tabular}


SD: standar deviasi; KV: koefisien variasi; Min.: nilai minimum; Maks.: nilai maksimum Tabel 6. Rata-rata Ukuran Tubuh pada Sapi Lokal Umur 3 Tahunan di Indonesia

\begin{tabular}{lccccl}
\hline \multirow{2}{*}{ Bangsa } & \multirow{2}{*}{ Sex } & \multicolumn{3}{c}{ Ukuran tubuh $(\mathrm{cm})$} & \multirow{2}{*}{ Sumber } \\
\cline { 3 - 6 } & & TG & PB & LD & \\
\hline \multirow{2}{*}{ Aceh } & Jantan & $99,18 \pm 5,04$ & $101,29 \pm 5,18$ & $133,29 \pm 6,00$ & \multirow{2}{*}{ Abdullah et al. } \\
& Betina & $98,69 \pm 4,13$ & $99,04 \pm 6,33$ & $126,41 \pm 8,12$ & $(2007)$ \\
\hline \multirow{2}{*}{ Bali } & Jantan & $107,59 \pm 6,11$ & $103,84 \pm 13,49$ & $139,06 \pm 12,39$ & Tonbesi et al. \\
& Betina & $107,29 \pm 6,32$ & $106,00 \pm 11,31$ & $140,65 \pm 15,19$ & $(2009)$ \\
\hline \multirow{2}{*}{ Madura } & Jantan & $132,50 \pm 10,50$ & $130,50 \pm 17,23$ & $161,75 \pm 16,17$ & Setiadi dan \\
& Betina & $117,00 \pm 4,24$ & $123,00 \pm 2,83$ & $126,00 \pm 7,07$ & Diwyanto $(1997)$ \\
\hline \multirow{2}{*}{ PO } & Jantan & $132,90 \pm 5,50$ & $132,10 \pm 7,60$ & $163,30 \pm 11,00$ & Hartati et al. \\
& Betina & $125,70 \pm 5,10$ & $134,30 \pm 7,60$ & $157,10 \pm 12,50$ & (2009) \\
\multirow{2}{*}{ Katingan } & Jantan & $121,10 \pm 13,30$ & $128,40 \pm 9,90$ & $157,10 \pm 18,10$ & Utomo et al. \\
& Betina & $100,60 \pm 5,00$ & $115,60 \pm 7,40$ & $137,00 \pm 6,60$ & (2010) \\
\hline \multirow{2}{*}{ Peisisir } & Jantan & $98,20 \pm 5,20$ & $107,00 \pm 3,10$ & $124,20 \pm 9,10$ & Adrial (2010) \\
& Betina & $97,80 \pm 4,00$ & $106,70 \pm 6,10$ & $122,60 \pm 6,50$ & \\
\hline
\end{tabular}

Hasil penelitian menunjukkan bahwa berat awal dan nilai $\mathrm{NP}_{550}$ pada sapi tidak sepenuhnya mempengaruhi berat akhir selama pengujian (Tabel 7). Hal itu disebabkan karena kemungkinan terjadi kompetisi pakan diantara ternak dalam kandang koloni. Oleh sebab itu sebaiknya sapi yang diuji performans dipelihara di kandang individu. Dengan demikian sapi yang diuji dapat dikontrol pakannya.

\section{Ukuran Tubuh dan Tipe Kelas}

Rata-rata ukuran tubuh pada sapi Aceh tersaji pada Tabel 5. Ukuran tubuh sapi Aceh jantan setelah uji performans pada penelitian ini belum memenuhi SNI bibit Aceh. Hal itu kemungkinan disebabkan karena ukuran tubuh sapi Aceh pada rata-rata umur kurang dari 1000 hari belum memenuhi syarat SNI. Hasil penelitian Abdullah et al. (2007) menunjukkan bahwa rata-rata ukuran tubuh TG, PB dan LD pada sapi Aceh jantan umur 4 tahun masing-masing sebesar 105,56 $\pm 4,76 \mathrm{~cm}, 107,69 \pm 5,68 \mathrm{~cm}$ dan $138,69 \pm 2,28 \mathrm{~cm}$. Hasil penelitian tersebut memberikan informasi bahwa ukuran tubuh TG dan PB berdasarkan SNI termasuk kelompok tipe kelas C.

Ukuran tubuh pada sapi Aceh betina setelah pengujian menunjukkan nilai yang lebih besar dibandingkan dengan SNI dan termasuk kelompok kelas A. Hal itu disebabkan karena ukuran tubuh sapi betina tersebut diukur pada saat berumur lebih dari 18 bulan, sehingga ukuran tubuhnya akan lebih tinggi dibandingkan dengan saat berumur 18 bulan. Hasil penelitian menunjukkan bahwa rata-rata ukuran $\mathrm{TG}$ dan $\mathrm{PB}$ sapi Aceh pada penelitian ini dan sebelumnya memiliki nilai yang lebih kecil dibandingkan sapi Bali, Madura, PO dan Katingan, tetapi memiliki kisaran nilai yang sama pada sapi Pesisir seperti pada Tabel 6.

Seleksi pada ukuran tubuh terutama TG dan PB perlu dilakukan pada sapi Aceh agar dapat memenuhi kriteria SNI. Pengukuran awal sebelum uji performans perlu dilakukan agar sapi yang dihasilkan sesuai SNI. Disarankan ukuran TG dan PB minimum sebelum pengujian adalah sebesar $100 \mathrm{~cm}$. 
Tabel 7. Performans Sembilan Sapi Aceh Terbaik Berdasarkan Hasil Uji Performans selama 369 hari di BPTU-HPT Sapi Aceh Indrapuri

\begin{tabular}{|c|c|c|c|c|c|c|c|c|c|c|}
\hline $\begin{array}{l}\text { Sex / } \\
\text { Rank }\end{array}$ & No. sapi & $\begin{array}{l}\text { Umur } \\
\text { (hari) }\end{array}$ & $\begin{array}{l}\text { NP } \\
550\end{array}$ & $\begin{array}{c}\mathrm{TG} \\
(\mathrm{cm})\end{array}$ & $\begin{array}{c}\text { PB } \\
(\mathrm{cm})\end{array}$ & $\begin{array}{l}\text { LD } \\
(\mathrm{cm})\end{array}$ & $\begin{array}{c}\text { BL } \\
(\mathrm{kg})\end{array}$ & $\begin{array}{r}\text { BAT } \\
(\mathrm{kg})\end{array}$ & $\begin{array}{c}\text { BFT } \\
(\mathrm{kg})\end{array}$ & $\begin{array}{l}\text { Tipe } \\
\text { kelas }\end{array}$ \\
\hline & & & & & \multicolumn{6}{|c|}{ 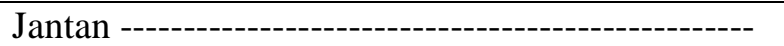 } \\
\hline 1 & A100517 & 977 & 19,52 & 103 & 105 & 124 & 12 & 138,71 & 166,71 & - \\
\hline 2 & A100503 & 981 & 4,59 & 103 & 101 & 132 & 12 & 132,28 & 164,28 & - \\
\hline 3 & A1004 & 884 & 8,57 & 101 & 97 & 128 & 14 & 122,31 & 163,31 & - \\
\hline 4 & A100125 & 1083 & 2,99 & 110 & 103 & 131 & 12 & 136,13 & 158,13 & - \\
\hline 5 & A100314 & 1037 & 8,67 & 100 & 99 & 129 & 14 & 137,11 & 157,11 & - \\
\hline 6 & A100707 & 964 & 6,83 & 100 & 96 & 125 & 12 & 114,33 & 153,33 & - \\
\hline 7 & A100113 & 1104 & 11,63 & 107 & 97 & 125 & 12 & 117,12 & 150,12 & - \\
\hline 8 & A100410 & 1011 & 7,05 & 96 & 94 & 121 & 14 & 120,18 & 142,18 & - \\
\hline 9 & A100802 & 895 & 5,15 & 97 & 103 & 120 & 13 & 116,74 & 141,74 & - \\
\hline 1 & A100302 & 1066 & 17,96 & 105 & 101 & 145 & 15 & 157,19 & 214,19 & A \\
\hline 2 & A216 & 935 & 27,62 & 94 & 103 & 130 & 13 & 146,13 & 180,13 & A \\
\hline 3 & A100408 & 1027 & 29,50 & 97 & 97 & 127 & 13 & 147,88 & 166,88 & A \\
\hline 4 & A100807 & 899 & 13,32 & 101 & 99 & 136 & 12 & 125,89 & 163,89 & A \\
\hline 5 & A100404 & 1030 & 11,19 & 101 & 101 & 129 & 14 & 125,08 & 162,08 & A \\
\hline 6 & A100810 & 888 & 3,98 & 92 & 98 & 117 & 13 & 111,35 & 157,35 & A \\
\hline 7 & A100607 & 948 & 13,50 & 96 & 100 & 128 & 13 & 115,71 & 152,71 & A \\
\hline 8 & A1015 & 904 & 12,36 & 97 & 99 & 119 & 12 & 123,04 & 152,04 & A \\
\hline 9 & A100126 & 1098 & 7,61 & 103 & 99 & 128 & 13 & 110,82 & 149,82 & A \\
\hline
\end{tabular}

BAT: berat awal terkoreksi; BFT: berat final (akhir) terkoreksi; $\mathrm{NP}_{550}$ : nilai pemuliaan berat badan umur 550 hari; TG: tinggi gumba; PB: panjang badan; LD: lingkar dada; BL: berat lahir

Uji performans pada sapi betina sebaiknya tidak dilakukan karena menyebabkan umur pertama kali kawin menjadi lebih tinggi ( \pm 3 tahun) dan hasil yang diperoleh tidak sesuai SNI. Sebaiknya seleksi pada sapi Aceh betina di lokasi penelitian ini berdasarkan pada

\section{UCAPAN TERIMA KASIH}

Penulis mengucapkan terima kasih kepada seluruh staf dan karyawan di BPTU-HPT Sapi Aceh Indrapuri atas bantuan dan dukungannya sehingga penelitian ini dapat diselesaikan dengan baik.

\section{DAFTAR PUSTAKA}

Abdullah, M.A.N., R.R. Noor, H. Martojo, D.D. Solihin dan E. Handiwirawan. 2007. Keragaman berat umur kisaran 550 hari. Dalam penelitian terlihat bahwa rata-rata sapi Aceh betina yang berumur \pm 600 hari (sebelum pengujian) memiliki ukuran tubuh yang termasuk tipe kelas B.

fenotipik sapi Aceh di Nanggroe Aceh Darussalam. J. Indonesian Trop. Anim. Agric. 32(1): 11-21

Adinata, Y. 2013. Estimasi nilai pemuliaan bobot lahir sapi Peranakan Ongole pada Unit Pengelolaan Bibit Sumberdi Loka Penelitian Sapi Potong. Proseding Seminar Nasional Teknologi Peternakan dan 
Veteriner, Medan, 3 - 4 September 2013. Hlm. 66-73

Adrial. 2010. Potensi sapi Pesisir dan upaya pengembangannya. Jurnal Litbang Peternakan. 29(2): 6672

DJPKH. 2015. Statistik Peternakan dan Kesehatan Hewan. Direktorat Jenderal Peternakan dan Kesehatan Hewan. Kementerian Pertanian RI, Jakarta.

Fitri, C.A. 1991. Perbandingan Karkas dari Spesies Sapi. http://www.poliven.ac.id. Agustus 2016)

Gunawan, D. Pamungkas dan L. Affandhy. 1998. Sapi Bali, Potensi, Produktivitas dan Nilai Ekonomi. Kanisius, Yogyakarta.

Hardjosubroto, W. 1994. Aplikasi Pemuliabiakan Ternak di Lapangan. Gramedia Widiasarana, Jakarta.

Hartati, Sumadi dan T. Hartatik. 2009. Identifikasi karakteristik sapi Peranakan Ongole di peternakan rakyat. Buletin Peternakan. 33(2): 64-73

Kaswati, Sumadi dan N. Ngadiono. 2013. Estimasi nilai heritabilitas berat lahir, berat sapih dan umur satu tahun pada sapi Bali di Balai Pembibitan Ternak Unggul Sapi Bali. Buletin Peternakan. 37(2): 74-78.

Kolkman, I., G. Opsomer, S. Aerts, G. Hoflack, H. Leavens and D. Lips. 2010. Analysis of body measurements of newborn purebred Belgian Blue calves. Animal. 4(5): 661- 671.
Mashiloane, L, A. Bothma, K. Madia, J. Sebei and K. Nephawe. 2012. Growth and feed efficiency of range performance tested beef bulls in the arid sweet bushveld of South Africa. J. Anim. Sci. 2(4): 258-264

Muslim, K.N., N. Hary dan S. Trinil. 2011. Hubungan antara berat badan induk dengan berat lahir pedet sapi Brahman cross pada jenis kelamin yang berbeda. JIIP. 23(1): 18-24.

Nahar, S, A.F.M. F. Islam, M.A. Haque and A.K.F.H. Bhuiyan. 2016. Animal performance of indegenous Red Chittagong cattle of Bangladesh. Acta Scientiarum. 38(2): 177-182.

Nandolo, W, N.G. Timothy, and B. Mcloyd. 2016. Phenotypic and genetic parameters of calf growth traits for Malawi Zebu. LRRD. 28(2). $\mathrm{http} / /$ : www.lrrd.org. (23 Agustus 2016)

Nugent, R.A., D.R. Notter and W.E. Beal. 1991. Body measurements of newborn calves and relationship of calve shape to sire breeding values for birth weight and calving ease. J. Anim. Sci. 69(6): 2413-2421.

Ozkaya, S. 2013. The prediction of live weight from body measurements on Holstein calves by digital image analysis. J. Agric. Sci. 151: 570-576.

Patmawati, N.W., N.Y. Trinayani, M. Siswanto, I.N. Wandia dan I.K. Puja. 2013. Seleksi awal pejantan sapi Bali berbasis uji performans. JIKH. 1(1): 29-33 
Rabeya, T, A.K.F.H. Bhuiyan, M.A. Habib and M.S. Hossain. 2009. Phenotypic and genetic parameters for growth traits in Red Chittagong cattle of Bangladesh. J. Bangladesh. Agril. Univ. 7(2): 265-271.

Said, S., P.P. Agung, W.P.B. Putra, S. Anwar, A.S. Wulandari dan A. Sudiro. 2013. Estimation of most probable producing ability value for calf birth's performance in Sumba Ongole cows. J. Indonesian Trop. Anim. Agric. 41(2): 53-60

Setiadi, B. dan K. Diwyanto. 1997. Karakterisasi morfologis sapi Madura. JITV. 2(4): 218- 224.

Supiyono. 1998. Ilmu Tilik Ternak. Gadjah Mada University Press, Yogyakarta.

Tatiane, C.S.C., L.C. Sabrina, E.B. Marcos, D.A.G. Daniela, G.F.G. Diego, B.D.N. Guilherme, O.R. Jaqueline, B.R. Raysildo and M. Danisio. 2014. Genetic analysis for gestation length, birth weight, weaning weight and accumulated productivity in Nellore beef cattle. Livest. Sci. 170: 16-21.

Tonbesi, T.T., N. Ngadiono dan Sumadi. 2009. Estimasi potensi dan kinerja di Kabupaten Timor Tengah Utara, Provinsi Nusa Tenggara Timur. Buletin peternakan. 33(1): 30- 39

Utomo, B.N., R.R. Noor, C. Sumantri, I. Supriatna dan E.D. Gunardi. 2010. Keragaman morfometrik sapi Katingan di Kalimantan Tengah. JITV. 15(3): 220-230.

Warwick, E.J., M. Astuti dan W. Hardjosubroto. 1989. Pemuliaan Ternak. Gadjah Mada University Press, Yogyakarta

Yusran, M.A., K. Ma'sum dan D.B. Wijono. 1995. Evaluasi nilai pemuliaan calon pejantan donor semen beku sapi Madura melalui program uji keturunan. JIPT. 4(1): 17-23.

Yusuf, M., J.A. Syamsu, L. Rahim dan H.M. Ali. 2010. Studi uji performans ternak sapi Bali di Kabupaten Barru, Sulawesi Selatan (Preliminary Study). Proseding Seminar Nasional Peningkatan Akses pangan Hewani melalui Integrasi Pertanian-Peternakan berkelanjutan Menghadapi Era ACFTA. Fakultas Peternakan, Universitas Jambi， Jambi， 23 Juni 2010. Hlm. 1-11 